\title{
Alieksiêi Karamazov e a busca pela totalidade perdida
}

Luciana Brito

Ana Gabriela Dutra da Silva

Resumo: Na nova configuração que se instaura com o mundo burguês, a epopeia desaparece para dar lugar a uma nova forma que apresenta condições de lidar com esse mundo que não mais compreende a totalidade e o sentido de comunidade da epopeia clássica - o romance. O gênero romanesco, habitado por uma personalidade que, além de errante, é solitária e tem como tarefa individual a busca pela verdade, torna-se, assim, o texto representativo da era moderna. Tal gênero, então, passa a ser a epopeia de um mundo abandonado por Deus, no qual um herói degradado sai em busca de uma totalidade perdida, como é o caso da personagem a ser estudada neste artigo, Alieksiêi Karamázov.

Palavras-chave: Dostoiévski. Alieksiêi Karamázov. Personagem moderna.

Abstract: In the new configuration that is established with the bourgeois world, the epic disappears to make way for a new form that is in a position to deal with this world that no longer understands the totality and the sense of community of classical epic - the novel. The novelistic genre, inhabited by a wandering and lonely personality whose individual task is the search for truth, becomes the representative text of the modern era. Such gender becomes the epic of a world abandoned by God which there is the presence of a degraded hero in search of a lost totality, such as the case of the character studied in this article - Alexei Karamazov.

Keywords: Dostoyevsky. Alexei Karamazov. Modern character.

Resumen: En la nueva configuración que, si instaura con el mundo burgués, la epopeya desapareció para dar lugar a la nueva forma que presenta condiciones de lidiar con ese mundo que no se comprende más en su totalidad y en el sentido de comunidad de la epopeya clásica - el romance. O género romanesco, habilitado por

1 Doutora em Letras pela Universidade Estadual Paulista, docente do Centro de Letras, Comunicação e Artes da Universidade Estadual do Norte do Paraná e do Programa de PósGraduação em Letras da Universidade Estadual de Londrina.

${ }^{2}$ Mestre em Letras pelo Programa de Pós-graduação em Letras da Universidade Estadual de Londrina e pesquisadora do Núcleo Institucional de Pesquisa da Universidade Estadual do Norte do Paraná.

Este artigo está licenciado sob forma de uma licença Creative Commons Atribuição 4.0 Internacional,

que permite uso irrestrito, distribuição e reprodução em qualquer meio, desde que a publicação

original seja corretamente citada. https://creativecommons.org/licenses/by/4.0/deed.pt BR. 
una personalidad que, aparte de errante, es solitario y tiene como tarea individual la búsqueda por la verdad, convertirse, así, el texto representativo de la era moderna. Tal género, entonces, podría pasar a ser una epopeya de un mundo abandonado por Dios, en el cual un héroe degradado sale en busca de una totalidad perdida, como es el caso del personaje a ser estudiada en este artículo, Aliesiêi Karamázov.

Palabras-clave: Dostoievski. Alieksiêi Karamázov. Personaje moderno.

Os Irmãos Karamázov (1880) foi o último livro escrito por Dostoiévski antes de sua morte em 1881. Nele, é possível acompanhar, por meio do ponto de vista onisciente de um narrador-testemunha, a história da família Karamázov e suas relações com os acontecimentos de um pequeno e afastado distrito da Rússia do século XIX. A família Karamázov é composta por quatro membros, sendo eles: Fiódor Pávlovitch Karamázov e seus filhos Dmitri, Ivan e Alieksiêi. O patriarca da família é descrito como um fazendeiro de "tipo estranho", um "homem não só reles e devasso, mas ao mesmo tempo bronco", que se casara duas vezes (DOSTOIÉVSKI, 2008, p.17).

De seu primeiro casamento, teve Dmitri com uma mulher rica e nobre que efetivou o desejo do velho de "arranjar sua carreira fosse lá como fosse, de fazer parte de uma boa família e receber um dote, comprovando que ele realmente não passava de um "palhaço perverso" (DOSTOIÉVSKI, 2008, p.17-18). O filho mais velho de Fiódor foi abandonado pela mãe com apenas três anos de idade e deixado aos cuidados de um primo de sua família materna que acabou entregando o menino a uma de suas tias de segundo grau. Fiódor Pávlovitch casou-se pela segunda vez com uma órfã "sem família desde a infância, filha de um obscuro diácono, que crescera na casa rica de sua benfeitora, educadora e carrasca" (DOSTOIÉVSKI, 2008, p.24). Ainda que a mulher 
sofresse de histeria, deu ao velho dois filhos, Ivan e Alieksiêi, que, após a morte da esposa, também foram abandonados pelo pai.

Alieksiêi Karamázov, considerado no prefácio do romance "um herói tão modesto e indefinido" pelo próprio Dostoiévski (2008, p.14), na ocasião, com apenas vinte anos, é descrito inicialmente como um jovem imbuído de um precoce amor ao ser humano, que escolheu viver em um mosteiro, pois buscava uma saída para sua alma, que "tentava arrancarse das trevas da maldade mundana para a luz do amor" (DOSTOIÉVSKI, 2008, p.32).

O sonho de Alieksiêi, como um ideólogo em maior ou menor grau (BAKHTIN, 1988), era o de encontrar uma força que estabeleceria a verdade na Terra, por meio da qual todos amariam uns aos outros, não haveria distinção de classes, todos seriam filhos de Deus e se estabeleceria o verdadeiro reino de Cristo. Este desejo da personagem representa a busca pela totalidade a qual se lança o herói romanesco, conforme afirma Lukács (2009), ou seja, a peregrinação que tem como intenção a reconciliação entre herói e mundo. Em outras palavras, o anseio da referida personagem pode ser equiparado com a totalidade antes presente na era epopeica perfeita e acabada, na qual o herói abrigava em sua alma a certeza de um caminho guiado pelos deuses e que, por esse motivo, não conhecia em si mesmo nenhum abismo que pudesse atraí-lo à queda ou impeli-lo a alturas inacessíveis.

Alieksiêi é descrito como alguém "que não queria ser juiz dos homens, que não queria assumir sua condenação e por nada os condenaria. Parecia até que admitia tudo, sem qualquer condenação, embora tomado amiúde de uma tristeza muito amarga" (DOSTOIÉVSKI, 2008, p.33) e que, ao contrário de seu pai e seu irmão Dmitri, parecia não 
ter "nenhuma noção do dinheiro, não no sentido literal, é claro" (DOSTOIÉVSKI, 2008, p.36). Característica essa que, diferente do que ocorre com o restante da família Karamázov, não aguça a desconfiança do leitor em relação à pureza de Alieksiêi, já que é confirmada, inclusive, por muitas das outras personagens, como é o caso do próprio Fiódor.

Frank (2007, p.723), no que diz respeito a essa pureza presente em Alieksiêi, ratifica que a descrição do caráter e do comportamento da personagem não é nem sequer intencionada pelo narrador e que, além disso, a sua pureza moral e o amor que despertava em todos podem ser comparadas às características dos santos:

As forças que o movem, deixadas deliberadamente vagas para sugerir uma possível inspiração extraterrena, derivam das impressões de infância [...] e da natureza da vocação religiosa que inspiraram. Não é por acaso, obviamente, que seu homônimo, Santo Aleksiéi, o Homem de Deus, é mencionado [...]. Assim, Aliocha é instintivamente religioso e instintivamente devoto. Até que sua fé seja testada mais tarde no livro, ele não tem dúvidas no tocante à Deus e à imortalidade, nem mesmo à verdade das lendas milagrosas ligadas à instituição dos anciãos [...], a classe especial de monges a que pertencia o padre Zóssima (FRANK, 2007, p.723).

Entretanto, com o passar do tempo, o narrador-testemunha começa, por meio dos discursos de outras personagens, a colocar em dúvida essa pureza incontestável da referida personagem dostoievskiana. Quando ele sai do mosteiro onde estava há um ano e que "parecia disposto a enclausurar-se [...] pelo resto da vida" (DOSTOIÉVSKI, 2008, p.32) e, consequentemente, da proteção divina de seu stárietz Zóssima, iniciam-se afirmações como "Ora, também é um Karamázov! Porque em tua família a lascívia chega a ser uma doença infecciosa”; “Tu, Aliócha, és um sonso, um santo, concordo, mas um santo do pau oco, e o diabo sabe 
o que já terás pensado, o diabo sabe o que já conheces! [...]. Tu mesmo és um Karamázov, um Karamázov completo” (DOSTOIÉVSKI, 2008, p. 125-126); "E todos nós, Karamázov, somos assim; até em ti, anjo, esse inseto vive e em teu sangue gera tempestades" (DOSTOIÉVSKI, 2008, p.162).

Alieksiêi só fez a escolha de ir para o mosteiro exatamente por ter sido esse o único caminho "que o fascinou naquele momento e ao mesmo tempo lhe ofereceu todo o ideal para a saída de sua alma, que tentava arrancar-se das trevas para a luz" (DOSTOIÉVSKI, 2008, p.44). Essa escolha de Alieksiêi de ir para o mosteiro para se salvar da maldade mundana ilustra bem a primeira fase pela qual passa a personagem - a certeza e a confiança de acreditar e querer ser benevolente. No entanto, por ser o herói romanesco a incontestável representação do indivíduo que habita o mundo moderno, no qual estrutura e fisionomia individuais nascem da reflexão polêmica que se volta para si própria, da personalidade que, além de errante, é solitária (LUKÁCS, 2009), Alieksiêi acaba descobrindo que a benevolência que almeja e que acredita ter em sua alma não é possível tendo em vista a realidade que o rodeia. Essa questão está relacionada com o fato do mundo moderno tornar a busca antes auxiliada pelos deuses em uma busca solitária. $\mathrm{O}$ isolamento humano é consequência da modernidade que não mais abriga a possibilidade de se alcançar o objetivo almejado, bem como da perda do sentido de comunidade antes presente na era clássica e que expressa as categorias resultantes do capitalismo recém-chegado em território russo, fundando, assim, uma sociedade solidificada em "formas de vida 'puramente sociais', que então não são mais, doravante, 'naturais'” (FEHÉR, 1972, p.11). 
Torna-se digno de atenção o modo como "Aliócha apenas escolheu um caminho oposto ao de todos os outros, mas com a mesma sede de um feito imediato" (DOSTOIÉVSKI, 2008, p.46); assim como todas as outras personagens centrais, Alieksiêi defronta-se "com a mesma necessidade de dar um salto de fé em alguma coisa ou alguém" para além de si mesmo (FRANK, 2007, p.716), visto que sua alma "cheia de êxtase ansiava por liberdade, por espaço, por amplitude" (DOSTOIÉVSKI, 2008, p.488). Afinal, nas palavras de Ivan direcionadas a seu irmão caçula, "essa vontade de viver a despeito de qualquer coisa é um traço dos Karamázov, é verdade, e ela também existe infalivelmente em ti" (DOSTOIÉVSKI, 2008, p.318).

A desconfiança inicial do leitor em relação a essa pureza não condizente com uma família, na qual "espécie e seleção significam alguma coisa" (DOSTOIÉVSKI, 2008, p.126), bem como a percepção de Alieksiêi de que a benevolência ambicionada ao lado do stárietz está impossibilitada de existir, fortalecem-se ainda mais no episódio em que a referida personagem e Ivan - seu irmão uterino - conversam em um botequim, expondo opiniões que perpassam o ateísmo e o liberalismo do irmão e a religiosidade até então inabalável de Aliócha. Em meio à discussão de ideais, Ivan apresenta para Alieksiêi um poema intitulado "O Grande Inquisidor", que afirma ter inventado e guardado na memória.

O poema se passa no século XVII, em Sevilha, Espanha, na época da Inquisição, e traz o encontro entre um velho cardeal inquisidor de "quase noventa anos, alto e ereto, rosto ressequido e olhos fundos" e Cristo, caracterizado por um "sorriso sereno da infinita compaixão" e por mãos que irradiam a força que cura (DOSTOIÉVSKI, 2008, p.344-346). Ao contrário de como foi recebido pelo povo que o reconhece e se 
precipita para ele, assediando-o, avolumando-se ao seu redor e seguindoo, Cristo é trancado em uma "prisão apertada e sombria", onde "cai a noite quente, escura e 'sem vida", na qual "em meio a trevas profundas" (DOSTOIÉVSKI, 20o8, p.347), o Grande Inquisidor o recebe com uma ameaça:

te julgo e te queimo na fogueira como o mais perverso dos hereges, e aquele mesmo povo que te beijou os pés, amanhã, ao meu primeiro sinal, se precipitará a trazer carvão para tua fogueira, sabias? É, é possível que o saibas [...] (DOSTOIÉVSKI, 2008, p.347).

O Grande Inquisidor começa, então, a questionar Cristo por ter proporcionado e defendido o livre-arbítrio dos homens por todo o tempo em que esteve na Terra, já que considera a liberdade o que há de mais insuportável para o homem e para a sociedade humana. Esse fardo mencionado pelo Grande Inquisidor, no que diz respeito ao livrearbítrio, exprime a inquietude e o tormento que se instauram no homem moderno, visto que a liberdade traz a responsabilidade de se fazer escolhas, e a tomada de consciência da liberdade é acompanhada do receio de usá-la de maneira equivocada. Cristo, então, continua em silêncio e o velho Inquisidor começa a culpá-lo por ter prometido o pão dos céus aos famintos da "tribo humana, eternamente impura e eternamente ingrata" (DOSTOIÉVSKI, 2008, p.352) e afirma que Cristo foi um tolo por não ter se assenhoreado da liberdade humana ao invés de aumentá-la ainda mais, pois os homens jamais poderão ser livres, já que, estando livres, procuram desesperadamente a quem se sujeitar.

O Grande Inquisidor continua a acusar Cristo por ter reivindicado as três tentações oferecidas pelo "terrível e sábio espírito" no deserto, 
capazes de "cativar para sempre a consciência desses rebeldes fracos", sendo elas o milagre, o mistério e a autoridade. Afirma ainda que Cristo superestimou o homem e que por isso exigiu demais dele, deixando à humanidade um fardo mais pesado do que poderia carregar, por ser ela fraca e torpe. Ao invés de proporcionar o bem com a liberdade que tanto defendeu, causou somente intranquilidade, desordem e infelicidade. Continua o sermão ao confirmar que ele e seus apoiadores corrigiram a façanha cristã ao tomarem como fundamento as três forças oferecidas pelo demônio no deserto e as proporcionarem aos homens com a necessidade de uma união universal.

O velho cardeal, então, incrimina Cristo por ter priorizado somente os mais fortes e abandonado os fracos, enquanto ele proporciona felicidade e tranquilidade a todos sem exceção. Salienta repetidamente a importância da união universal e da autoridade perante a humanidade, pois a grande preocupação e os terríveis tormentos são fruto de "uma decisão pessoal e livre" - o livre-arbítrio, do qual Cristo foi o responsável por instituir no homem e desmembrá-los por caminhos desconhecidos. O poema, então, termina com o Grande Inquisidor esperando de Cristo uma resposta, já que "era pesado o silêncio do outro" (DOSTOIÉVSKI, 2008, p.364). Porém, Cristo mantém-se com ar convicto e sereno, fitando-o nos olhos sem fazer objeção alguma. De repente, levanta-se, aproxima-se do velho cardeal e em "silêncio e calmamente lhe beija a exangue boca de noventa anos" (DOSTOIÉVSKI, 2008, p.364). O velho estremece e manda que Cristo saia e nunca mais volte, o prisioneiro levanta-se, beija o Inquisidor nos lábios e vai embora.

O referido poema de Ivan mostra Cristo e o Grande Inquisidor como figuras opostas, sendo o primeiro um símbolo de liberdade, e o 
segundo, um símbolo de autoridade, opressão e aprisionamento. Enquanto Cristo renega o milagre, o mistério e a autoridade oferecidos pelo demônio no deserto e as considera tentações, o velho cardeal as enxerga como ferramentas para o controle da humanidade. Ao mesmo tempo em que Cristo defende a liberdade de deixar o ser humano escolher entre o bem e o mal, o Inquisidor defende um amor humanitário, no qual não há liberdade, já que o livre-arbítrio só traz sofrimentos e angústia. Sendo assim, a missão do Grande Inquisidor e de seus apoiadores seria a de corrigir a façanha de Cristo - acabar com o reino de liberdade concedida por ele. Porém, ainda que o velho cardeal pareça de início uma presença negativa, Ivan parece retratá-lo, em meio às acusações feitas a Cristo, como um ser bondoso que sofre pela humanidade toda ao invés de simplesmente ter adotado a postura egoísta de deixar a Terra com a simples capacidade de se escolher entre o bem e o mal, em que somente os "eleitos" sobrevivem.

Há, então, um embate entre individual e universal, exatamente o contrário do que seria necessário para que se alcançasse uma totalidade: a indispensável união entre o estado universal do povo com o feito individual (HEGEL, 2004), sendo o primeiro sustentado pelo livrearbítrio de Cristo, e o segundo defendido pelo anticristo - termo que se explica pelo Inquisidor se opor aos valores do Messias - pela consciência dominadora de que a humanidade é uma única união. A partir disso e considerando que, após o término do poema, Alieksiêi, assim como Cristo faz com o Grande Inquisidor, levanta-se e beija a boca do irmão, torna-se inevitável não perceber no mais novo membro da família Karamázov um duplo com o Cristo retratado no poema, já que até 
mesmo Ivan - o próprio autor - grita: "Plágio literário!" (DOSTOIÉVSKI, 2008, p.365).

Inicialmente, Alieksiêi e Cristo são descritos semelhantemente, sendo possível, então, afirmar que Alieksiêi inicialmente, assim como Cristo, é uma representação positiva de sentimentos como liberdade, por exemplo. Entretanto, apesar das semelhanças iniciais, conforme a história vai se desenrolando, Alieksiêi assume certas posturas distintas em relação às de Cristo relatadas por seu irmão. O Grande Inquisidor afirma repetidamente como o Messias rejeitou as tentações do diabo no deserto: "Tu rejeitaste a primeira, a segunda e a terceira e deste pessoalmente o exemplo para tal rejeição" (DOSTOIÉVSKI, 2008, p.354). O filho mais novo de Fiódor Pávlovitch Karamázov, porém, não faz o mesmo quando seu irmão o tenta como um duplo do Diabo e isso parece ser uma das diferenças mais gritantes entre ele e a figura de Cristo relatada no referido poema.

Alieksiêi sucumbe à tentação de Ivan, o irmão que "é exatamente esse tipo de idealista desesperado que desenvolveu a relação amor/ódio pela humanidade" (FRANK, 2007, p.363) e que o atormenta como um diabo no deserto, fazendo com que Aliócha tenha uma atitude diferente daquela que havia apresentado até então - uma atitude serena, não julgadora, uma atitude cristã. Aqui, já se inicia novamente e talvez de forma mais convincente a desconfiança proposta pelo narrador sobre a maldição do nome que o mais novo da família Karamázov carrega - kara em russo significa "castigo" e maz, radical do verbo mazat, significa "sujar, borrar", o que dá a ideia de um castigo sujo (DOSTOIÉVSKI, 2008, p.281). 
Torna-se pertinente apontar como a questão do duplo representada em Ivan/Alieksiêi, Ivan/Smerdiákov e Ivan/Diabo (BEZERRA, 2011) representa, de fato, aquele estado de uma consciência na qual se alojam, convivem e dialogam coisas às vezes até diametralmente opostas ou antagônicas, pondo a consciência "no movimento pendular entre aceitação e/ou recusa à consciência ou julgamento do outro, numa atitude às vezes desesperada para afirmar sua própria consciência” (BEZERRA, 2011, p.240).

Assim, a duplicidade da personagem moderna, que é, ao mesmo tempo, ela mesma e seu duplo, ao abrigar simultaneamente as forças do bem e do mal (ARTEAGA, 2011), apresenta-se como uma maneira de radicar o "pavor do homem diante da vida" e de manifestar as "formas de cisão da consciência" (BEZERRA, 2011, p.240) resultantes da nova configuração de mundo que não mais abriga a certeza epopeica do indivíduo invulnerável que abriga dois mundos - o sobrenatural e o humano -, mas que, ainda assim, não apresenta nenhuma ambiguidade (PAZ, 1976).

Ademais, essa duplicidade faz com que o indivíduo caia em uma rede de contradições tão grande que, ao se ver diante de problemas que exigem solução, acaba por não conseguir assumir uma posição decidida, pois, ao se deparar com uma saída, logo esbarra tanto em saídas que vão contra sua decisão, quanto a favor, o que vai de "questões aparentemente mais simples às mais complexas, como a existência ou inexistência de Deus" (BEZERRA, 2011, p.240-241), como é possível observar mais precisamente na discussão entre Alieksiêi e Ivan sobre a teoria do Grande Inquisidor. 
Retomando, ao fim do episódio, quando Aliócha se revolta com o poema do irmão e o questiona, Ivan responde: "Existe uma força que suporta tudo!”, então Alieksiêi o interroga: “Que força é essa?”, e a temida resposta é dada: "A dos Karamázov... a força karamazoviana da baixeza” (DOSTOIÉVSKI, 2008, p.364-365). Alieksiêi, então, como já mencionado e da mesma forma que Cristo faz com o Grande Inquisidor no poema, levanta-se e beija o irmão nos lábios. Porém, contrariamente ao Messias que apenas vai embora da mesma forma serena que chegou, Alieksiêi sente que "crescia-lhe no íntimo algo novo, para o que ele não tinha resposta" (DOSTOIÉVSKI, 2008, p.366); Cristo levanta-se e sai da escura prisão ao caminhar para a luz e abandonar o novo mundo que não mais o recebe sem desconfiança e ameaças, enquanto Aliócha parece caminhar diretamente para o abismo de que tanto almejava se salvar no início do primeiro volume do romance. Aqui, torna-se incontestável a passagem do estado de alma inicial de Alieksiêi da crença na busca por uma benevolência para um estado de aflição, de angústia, ao começar a perceber que apenas querer abrigar em si uma pureza incontestável, querer se tornar algo não é o suficiente, visto que o mundo em que está inserido aniquila qualquer possibilidade do triunfo de uma totalidade bem-sucedida.

Isso posto, torna-se pertinente salientar que da mesma forma da época da Inquisição espanhola, como o contexto do poema de Ivan, Cristo chega para tentar trazer paz e esperança em um período no qual isso se torna algo impossível - impossibilidade confirmada pela escolha de palavras utilizadas pelo narrador para descrever um ambiente onde não há luz: "prisão apertada, sombria”, "noite quente, escura e sem vida”, "em meio a trevas profundas", "porta de ferro da prisão" (DOSTOIÉVSKI, 
20o8, p.347) -, Alieksiêi, personagem de um contexto de transição histórico-filosófica (LUKÁCS, 2009) de uma Rússia na qual o capitalismo tardio ocasionou transformações avassaladoras e tornou as relações humanas cada vez mais caóticas, também tenta de várias maneiras se tornar o mediador de uma resolução dos conflitos em sua família de "pessoas cruéis, apaixonadas, lascivas, karamazovianas" (DOSTOIÉVSKI, 2008, p.329); tarefa dada pelo stárietz Zóssima e descrita por ele como "um grande infortúnio" (DOSTOIÉVSKI, 2008, p.121) e que, de fato, ao invés de um objetivo firme, despertou em Alieksiêi "apenas obscuridade e confusão" (DOSTOIÉVSKI, 2008, p.262). Tal tarefa dada a Alieksiêi representa bem a história de uma busca degradada em um mundo também degradado (GOLDMANN, 1976).

A benevolência, a fé, a esperança, antes seguramente almejadas por Alieksiêi, cedem lugar a um sentimento de angústia e agonia, principalmente quando a personagem entra em contato com sua família, que destrói todo sentimento de confiança de poder ser diferente. Nesta segunda fase da personagem, é interessante apontar a inquietação em que ela se encontra como resultado da ambição de se tornar algo, mas que se une ao entendimento de que não se pode ser o que se deseja ocasionado pelo contato com sua família como representação do que se tornou o mundo, pois, assim, ela passa a compreender que sua existência passa a significar solidão, que ela agora não é nada além de uma aparência, um objeto para si mesma (LUKÁCS, 2009). A própria personagem, inclusive, questiona sua capacidade de realizar a tentativa de reconciliação lhe dada como uma tarefa. A busca de Alieksiêi está diretamente relacionada à convicção de que a busca nunca alcançará seu objetivo porque, nas condições sociais burguesas, "não há possibilidade 
de reconciliação entre o eu e a sociedade, devido à desproporção que existe entre as aspirações da alma e a objetividade da organização social" (ANTUNES, 1998, p.183).

Para que se explique melhor esse conflito da personagem, é necessário que se considere, como já aludido, que na nova configuração de mundo não se torna mais possível a existência de uma totalidade espontânea do ser na realidade do presente, como na época das epopeias, visto que o mundo moderno anula, elimina, extingue o produto coletivo da epopeia, bem como o sentido positivo e depositário da vida grega: a totalidade (LUKÁCS, 2009), sendo a relação que se dá entre Alieksiêi e sua família uma retratação do indivíduo que tem seus ideais ampliados ao mesmo tempo em que a totalidade que busca se torna cada vez mais perdida como consequência da modificação histórico-filosófica do mundo.

Continuando, após esse episódio do Grande Inquisidor que causou tamanha inquietação em Alieksiêi, o primeiro volume do romance termina com a morte repentina e inesperada do stárietz Zóssima. Consequentemente, no início do segundo volume, o narradortestemunha, antes de continuar a estória, alerta que, após a morte do stárietz, aconteceu algo "tão inesperado para qualquer um de nós e tão contrário à esperança geral que [...] o relato minucioso e inquietante desta ocorrência até hoje continua extraordinariamente vivo na memória de nossa cidade e de todas as suas redondezas" (DOSTOIÉVSKI, 2008, p.445-446). Tal acontecimento é ilustrado pela "putrefação precoce" (DOSTOIÉVSKI, 2008, p.457) do corpo do amado stárietz e que causou em Alieksiêi, que já carregava "uma incerteza inquietante" (DOSTOIÉVSKI, 2008, p.307), uma enorme influência em seu coração, 
provocando-lhe "na alma uma espécie de reviravolta e uma mudança brusca" (DOSTOIÉVSKI, 2008, p.446), visto que ele acreditava fortemente que o corpo fosse produzir curas milagrosas.

Frank (2007, p.795) salienta a importância da morte do stárietz Zóssima ao afirmar que tal acontecimento fez com que Aliócha mergulhasse "no mais profundo pesar"; a referida personagem, de fato, "esperava a confirmação de sua crença na santidade do padre Zóssima. Todos os esforços escusatórios do narrador não conseguiram esconder que Aliócha, embora inspirado pela magnitude de seu amor, caíra como os outros na [...] tentação do Demônio" (FRANK, 2007, p.796). Inclusive, é exatamente após esse episódio que, pela primeira vez no romance, o narrador-testemunha sente permissão para "criticar a personagem que colocara sob sua proteção" (FRANK, 2007, p.796).

A inquietação iniciada pelo contato com a família tão impura e contrária ao que Alieksiêi buscava ao ir para o mosteiro e exacerbada pela conversa com o irmão Ivan a respeito da não permanência de Cristo na nova configuração de mundo, é somada aos sentimentos de desgosto e decepção vivenciados pela personagem ao sofrer a perda de um homem que considerava um santo, um ser divino, dada a expectativa do que aconteceria com o corpo do falecido. Essa questão torna ainda mais evidente na referida personagem a característica mais marcante de um herói moderno - a alma como palco de luta entre o bem e o mal, um "eu" no qual existem duas forças (MELETÍNSKI apud ARTEAGA, 2011): a dos valores cristãos adquiridos no mosteiro como uma busca pela totalidade e a da maldição dos Karamázov, carregada em seu sangue como uma representação da totalidade buscada e anulada pela crueldade do mundo moderno. 
O discurso da personagem Hippolit Kiríllovitch, advogado da acusação de parricídio feita contra Dmitri Karamázov no julgamento da morte de Fiódor Pávlovitch, considerado "um louco, como todos os seus filhos" (DOSTOIÉVSKI, 2008, p.310), ilustra bem essa questão ao descrever a "família moderna" (DOSTOIÉVSKI, 2008, p.903) de Alieksiêi como o bem e o mal numa mistura surpreendente que se une as “naturezas amplas, karamazovianas", capazes de encerrar todas as oposições possíveis e contemplar de uma vez "ambos os abismos, um abismo que está acima de nós, o abismo dos altos ideais, e o abismo que está abaixo de nós, o abismo da queda mais vil e funesta [...]. Dois abismos, dois abismos, senhores, em um só instante [...] (DOSTOIÉVSKI , 2008, p.903-905).

Assim, Alieksiêi, "com sua crise de dúvida, que, como as do Rei Lear e a de Hamlet [...] põe em questão toda a ordem do universo" (FRANK, 2007, p.713), entra em um conflito interno ocasionado pela percepção da ausência do divino no mundo em que reside, visto que na modernidade Deus não existe. Dito de outra forma, “destruindo-se nos homens a fé em sua imortalidade, neles se exaure de imediato não só o amor como também toda e qualquer força para que continue a vida no mundo. E mais: então não haverá mais nada amoral, tudo será permitido" (DOSTOIÉVSKI, 2008, p.110), o que ocasiona no homem moderno o sentimento de não saber mais o que fazer com as instituições de seu mundo. Ainda que ele as experimente como sempre mais transcendentais em relação à sua própria qualidade empírica, ele acaba simplesmente por não ter outra opção a não ser a de esquecê-las ou, pelo menos, esforçar-se no sentido de esquecê-las (FÉHER, 1972). 
Com a morte do stárietz, considerado um santo por Alieksiêi, um ser que tinha "no coração o mistério da renovação para todos, a força que finalmente" estabeleceria "a verdade na Terra” (DOSTOIÉVSKI, 2008, p.52) e com o caminho tomado "a passos rápidos" em "direção das portas de saída" (DOSTOIÉVSKI, 2008, p.457) do mosteiro para se envolver na resolução dos conflitos de seus familiares, a referida personagem adentra de maneira mais profunda a tomada de consciência de que sua alma, que antes abrigava a certeza, a fé e o desejo de se tornar algo, definitivamente cede lugar à decepção que acompanha o ceticismo e à descrença em si mesmo. Com a ânsia do indivíduo que tem a necessidade de se tornar algo, Alieksiêi, ao contrário do herói clássico, não nasce definido, mas se molda conforme enfrenta o mundo e acaba por se ver, em meio a sua peregrinação, cada vez mais rodeado por demônios.

Diferentemente do herói épico que é acompanhado e conduzido pelos deuses, sendo seu caminho envolvido por uma atmosfera de segurança, a personagem gradativamente se dá conta de que sua busca tem como palco um mundo no qual os deuses foram banidos e os que ainda não alcançaram o poder tornaram-se demônios (LUKÁCS, 2009). Como resultado, a psicologia do herói romanesco se torna demoníaca, já que ela se apresenta como o campo de ação do demoníaco, fazendo com que o conteúdo do romance se apresente como a história dessa alma perturbada que se identifica com o finito que, em seu entendimento, é o limite; o herói em busca de seu ideal passa a compreender o infinito que o limita, já que ou ele abdica de sua existência ou se aventura na busca da totalidade.

Considerando que "o diabo não poderia estar fora dessa, onde ele haveria de estar senão aqui?” (DOSTOIÉVSKI, 2008, p.969), a presença 
do demoníaco se apresenta de maneira mais perceptível nas personagens Ivan, como um duplo do próprio Diabo, como já aludido; em Smerdiákov, real assassino de Fiódor Pávlovitch e também um duplo de Ivan que reproduz, muitas vezes, a ideia de um mundo abandonado por Deus, no qual tudo é permitido; em Mikhail Ivánovitch Rakítin, colega seminarista da referida personagem, que mal podia esperar para assistir “à 'desonra do justo' e à provável 'queda' de Aliócha 'de santo a pecador”" (DOSTOIÉVSKI, 2008, p.462); em Lise, filha da senhora Khokhlakova, uma rica viúva amiga da família Karamázov, e que nutria uma paixão por Alieksiêi; além das outras personagens, como o próprio Dmitri e o pai, mas que, especificamente no caso de ambos, tendem para uma questão mais relacionada com o dinheiro cultuado como um deus, como "uma força despótica que destrói o psiquismo humano" (BEZERRA, 2011, p.242) do que com a presença do demoníaco na trajetória de Alieksiêi Karamázov como uma peregrinação do indivíduo problemático que busca a si mesmo (LUKÁCS, 2009).

Para que fique mais clara essa questão da presença dos demônios na vida da referida personagem, que vai percebendo aos poucos a real situação de um mundo abandonado por Deus (LUKÁCS, 2009), torna-se pertinente a menção de três episódios do segundo volume do romance, no qual Alieksiêi confessa seu contato com o demoníaco como uma inserção da personagem em uma realidade heterogênea, que carrega uma dimensão antes impossível de ser esboçada na epopeia - a das instituições humanas, nas quais se torna cada vez mais perceptível o dualismo (FEHÉR, 1972) do indivíduo que habita o mundo moderno e que não se adapta a seu destino ou a sua situação, pois ele ou é superior a seu destino ou inferior a sua humanidade por não se adequar 
totalmente na substância sócio-histórica de seu tempo, restando-lhe sempre um excedente de humanidade não realizado, uma necessidade de um futuro e de um lugar indispensável para ele (BAKHTIN, 1988).

O primeiro intitula-se, não sem intenção, "Um demoniozinho" e narra uma conversa entre Alieksiêi e Lise, na qual ela afirma sonhar com diabos e se divertir com isso; o segundo episódio acontece quando Alieksiêi visita seu irmão Dmitri na cadeia um dia antes do julgamento da morte de Fiódor Pávlovitch, no qual o mais velho confirma sua "psicologia da indecisão", seu "desacerto da presumida premeditação" (FRANK, 2007, p.372); e o terceiro e último exemplo escolhido se dá em uma discussão entre Alieksiêi e Ivan, quando a personagem, após o encontro descrito acima com Dmitri, assume saber que seu irmão uterino se sentia culpado pela morte do pai sem mesmo estar presente no momento em que Ivan confessa isso em uma de suas conversas com o Diabo.

De fato, Alieksiêi por vezes se mostra como um duplo de Ivan, como já mencionado, exatamente pelo fato de saber de algo que não viu e ser o único a confirmar a dúvida do irmão mais velho no que diz respeito à culpa pelo assassinato do pai, já que inúmeras vezes Ivan foi acusado por Smerdiákov, por exemplo, de saber de antemão que o parricídio aconteceria e, ainda assim, nada ter feito para evitá-lo.

Essa questão do duplo Ivan/Alieksiêi também pode ser comprovada pela passagem em que a referida personagem, após se revoltar pela morte do stárietz e ser provocado por Rakítin, que questiona "Então estás agora zangado com teu Deus, te rebelaste como quem diz: não prestaram as devidas honras a ele, nem o condecoraram para a festa! Sim senhor!", reproduz a fala do irmão: “Não é Deus que não 
aceito, entende isso, é o mundo criado por ele, o mundo de Deus que não aceito e não posso concordar em aceitar” (DOSTOIÉVSKI, 2008, p.325) sobre sua crença em Deus: “- Contra Deus eu não me rebelo, apenas 'não aceito o seu mundo"' (DOSTOIÉVSKI, 2008, p.46o-461). Logo depois, Alieksiêi intenciona quebrar o jejum ao consumir carne e bebida alcoólica, o que deixaria Ivan muito admirado, segundo Rakítin (DOSTOIÉVSKI, 2008, p.461).

Torna-se interessante apontar que, após o episódio já mencionado do conhecimento de Alieksiêi sobre o encontro de Ivan com o Diabo, a referida personagem ausenta-se do romance e o foco passa a ser os três encontros entre Smerdiakóv e Ivan, nos quais o irmão uterino de Aliócha se torna a única testemunha da confissão do verdadeiro assassino de seu pai, visto que Smerdiakóv se enforca na noite anterior ao julgamento do assassinato, logo depois de seu último encontro com o autor de "O Grande Inquisidor". Não por acaso, Alieksiêi volta a entrar em cena após a última conversa que Ivan trava com o Diabo, no qual este verbaliza seu papel nessa nova configuração de mundo que se instaura.

Retomando, Aliócha somente reaparece no romance ao interromper a última conversa de Ivan com o Diabo e, posteriormente, só volta a ter voz ao testemunhar a favor de Dmitri no julgamento da morte de seu pai. Torna-se claro o fato de que, nesse momento, se ainda houvesse em Alieksiêi alguma esperança e inocência, posteriormente ela seria aniquilada no epílogo do romance, no qual a referida personagem expressa sua opinião sobre a não aceitação do mundo em que vive, ao confirmar seu receio "de que nos tornemos maus" (DOSTOIÉVSKI, 2008, p.998). 
Ao largar "a sotaina” do mosteiro para vestir "uma sobrecasaca de belo corte" e "um macio chapéu redondo" (DOSTOIÉVSKI, 2008, p.692), Alieksiêi abandona o "ser raro" que buscava se tornar, chegando até mesmo a ser acusado em um jornal de ter "arrombado a caixa do mosteiro" e sumido com o stárietz (DOSTOIÉVSKI, 20o8, p.745). Como previsto por Kólia, que considerava "o Karamázov [...] um enigma” para si mesmo (DOSTOIÉVSKI, 2008, p.685), o misticismo da personagem é curado pelo "contato com a realidade" (DOSTOIÉVSKI, 2008, p.720), já que não se sabe realmente se um "Karamázov poderia, como Hamlet, pensar no que haverá além. Não [...], eles têm os seus Hamlets, já nós temos por enquanto os Karamázov!" (DOSTOIÉVSKI, 2008, p.925).

Em adição, a condenação de Dmitri, mesmo não sendo o responsável pelo assassinato do pai, e da morte do menino Iliúcha, tardiamente adorado por seus colegas de classe, comprovam e exacerbam mais ainda em Alieksiêi a percepção da crueldade do mundo que o recebe após sua saída do mosteiro, visto que o mundo agora criado para os homens por si mesmos não mais é um lar paterno, como era seu recolhimento junto ao stárietz, mas um aprisionamento, no qual a vida própria da interioridade só se torna possível e necessária quando a dessemelhança em meio aos homens se tornou um abismo insuperável no qual os deuses não existem e a interioridade se divorcia para sempre da aventura (LUKÁCS, 2009).

O desfecho do romance ilustra novamente a questão central que ronda os principais conflitos e dúvidas da referida personagem: a não existência do divino como representação de bondade na nova configuração de mundo da modernidade, na qual há apenas a presença de demônios. Tal ideia é ilustrada pela tomada gradual de consciência 
por Alieksiêi da extinção do sentimento de querer se tornar algo como resultado da exacerbação do entendimento de não poder ser o que almeja, já apontada anteriormente, e que faz com que a angústia e a inquietude resultem no sentimento de insatisfação e decepção pela incapacidade de cumprir a tarefa de reconciliação dada a ele pelo starietz Zóssima. Tal incapacidade ocorre exatamente pelo fato de não conseguir lidar com a própria realidade a sua volta quando se vê parte da família.

Alieksiêi, após todas as provações pelas quais passou durante os dois volumes do romance como uma tentativa de solucionar os problemas que rondavam sua família que sofre "da paixão mais impetuosa, mais karamazoviana" (DOSTOIÉVSKI, 2008, p.908), repleta de um "descomedimento louco e da susceptibilidade dos Karamázov", (DOSTOIÉVSKI, 2008, p.925), sentindo-se como parte da "barafunda karamazoviana, onde ninguém conseguia entender a si mesmo nem se definir" (DOSTOIÉVSKI, 2008, p.863), acaba por confirmar, como já aludido, seu receio "de que nos tornemos maus" (DOSTOIÉVSKI, 2008, p.998), visto que, segundo a própria personagem, o demônio "encarnouse nesse amor-próprio e infiltrou-se em toda uma geração" (DOSTOIÉVSKI, 2008, p.725).

Em outras palavras, Alieksiêi não possui aquela superação tanto externa quanto interna antes presente no herói épico; em sua trajetória, o membro mais novo dos Karamázov evidencia o fato de que a divindade se torna coadjuvante no mundo moderno, visto que Alieksiêi tem seu destino em suas próprias mãos, o que faz dele não um semideus como os heróis épicos, mas um herói problemático que carrega em si uma característica altamente humana que é incapaz de isentá-lo das vacilações, dos erros, das provações e dúvidas. 
A personagem inicia o romance como um mediador dos conflitos que acredita ter e poder carregar a benevolência em sua alma, mas acaba por se dar conta de que também faz parte deles ao sucumbir ao sentimento de inquietude que o leva à decepção, representando, assim, o indivíduo isolado, que não pode mais consegue falar exemplarmente sobre si mesmo e seus sentimentos, que não recebe conselhos e nem sequer sabe dá-los (BENJAMIN, 1985, p.201). Ao entrar em contato com seus demônios, Alieksiêi constata que o mundo buscado no mosteiro e na segurança de seu stárietz cede lugar ao mundo karamazoviano no qual Deus não existe; em contato com sua família, a solidez de sua fé esfarela no ar como argila seca e, ainda que tente se segurar em sua crença, acaba por perceber que é inútil lutar contra a realidade que o rodeia.

É possível perceber como Alieksiêi, ainda que munido inicialmente de sua inocência de crença em um mundo de amor cristão, realmente não é "um santo, como alguns canonizadores antigos e atuais de Dostoiévski querem incutir", mas "reúne em si todos os abismos da alma humana" (BEZERRA, 2008, p.XIII). Exatamente pelo fato de reunir em si esses "dois abismos extremos que um Karamázov pode contemplar", "essa natureza de duas faces, de dois abismos" (DOSTOIÉVSKI, 2008, p.945), a referida personagem flutua entre a busca por uma totalidade perdida e a consciência de que ela jamais será encontrada. Alieksiêi surge como uma representação da transição histórico-filosófica (LUKÁCS, 2009) a qual Dostoiévski estava vivenciando, a transição de dois séculos - final do século XIX e início do século XX - como palco da mudança da vida econômica e a substituição da economia de livre concorrência por uma economia de monopólios e de cartéis (GOLDMANN, 1976) que 
fazem com que o individualismo do século XVIII e a inclinação de alguns romancistas para a criação de um herói positivo como símbolo dos representantes de uma classe em ascensão seja levado ao desaparecimento pela tomada de consciência da degradação dos valores humanos trazidos por essa mesma civilização pela mercantilização de todas as relações. Tal transição somente evidenciou a exigência da modificação do gênero romanesco exatamente pelo fato de ser insuficiente um discurso monofônico para lidar com a fragmentação do indivíduo moderno que se mostrava cada vez mais indefinido.

Alieksiêi, ao entrar em contato com o inacabado, com o incompleto assim como a própria época que está se fazendo, é, de fato, um predecessor dessas personagens pertencentes ao processo de rarefação da literatura, que, ao invés de refletir o surgimento de um novo homem como queria Dostoiévski, acabou por ser a representação da desumanização do indivíduo como consequência da abolição de suas necessidades e ações em um mundo caótico no qual as relações humanas e a própria identidade vão se extinguindo exatamente por serem cada vez mais impossíveis de se expressar. Afinal, ainda vivemos em um mundo no qual "nosso horror está justamente no fato de que esses casos sombrios", como um parricídio, "já não nos horrorizam mais!" (DOSTOIÉVSKI, 2008, p.897) e, ao fim de todo julgamento em que a frase final for "Sim, é culpado!" (DOSTOIÉVSKI, 2008, p.969), o maior sentimento resultante estará relacionado com a angústia do esforço de conter a vontade de bater no peito e dizer em voz alta: "também sou um Karamázov" (DOSTOIÉVSKI, 2008, p.304). 


\section{Referências}

ANTUNES, L. Z. Teoria da narrativa: o romance como epopeia burguesa. Estudos de literatura e linguística. São Paulo: Arte e Ciência, 1998.

ARTEAGA, C. G. O herói da modernidade em Dostoiévski e Graciliano Ramos. 2011. $131 \mathrm{f}$. Tese (Doutorado em Literatura Comparada) - Universidade Federal do Rio Grande do Sul, Porto Alegre, 2011.

BAKHTIN, M. Questões de literatura e de estética: a teoria do romance. Tradução de Aurora Bernardini et al. São Paulo: Editora da Unesp, 1988.

BEZERRA, P. Posfácio. In: DOSTOIÉVSKI, F. Os Irmãos Karamázov. São Paulo: Editora 34, 2008.

. Posfácio. In: DOSTOIÉVSKI, F. O duplo. São Paulo: Editora 34, 2011.

DOSTOIÉVSKI, F. Os Irmãos Karamázov. São Paulo: Editora 34, 2008.

FEHÉR, F. O Romance Está Morrendo? Tradução de Eduardo Lima. Rio de Janeiro: Paz e Terra, 1972.

FRANK, J. Dostoiévski O Manto do Profeta: 1871 a 1881. São Paulo: EDUSP, 2007. GOLDMANN, L. Sociologia do romance. Tradução de Álvaro Cabral. Rio de Janeiro: Civilização Brasileira, 1976.

HEGEL, G. W. F. Curso de Estética. São Paulo: Editora da Universidade de São Paulo, 2004.

KLAUCK, A. P. O herói problemático de Georg Lukács: aplicação da teoria em Os Ratos, de Dyonélio Machado. Revista Voz das Letras, Concórdia, n. 12, 2009.

LUKÁCS, G. A Teoria do Romance: um ensaio histórico-filosófico sobre as formas da grande épica. Tradução de José Marcos Mariani de Macedo. São Paulo: Duas Cidades; Editora 34, 2009.

PAZ, O. A ambiguidade do romance. Signos em rotação. São Paulo: Perspectiva, 1976.

WATT, I. A ascensão do romance. São Paulo: Companhia das Letras, 1990.

Recebido em 13/o7/2017.

Aprovado em 09/10/2017. 